\title{
PECULIARITIES OF TRAINING OF FUTURE TEACHERS OF INCLUSIVE EDUCATION IN HIGHER EDUCATION INSTITUTIONS OF UKRAINE
}

\section{Shevtsiv Z. M., Filonenko M. M.}

\section{INTRODUCTION}

The reformation of the educational system in Ukraine requires a review of the professional training of teachers' in general secondary education institutions. The modernization of the educational process of higher education institutions in connection with the introduction of inclusive education deserves substantial attention. In accordance with the needs of modern practice, which are caused by dynamic changes, attention is paid to the formation of the professionalism of the teacher, his outlook culture, spiritual and moral face. Readiness and ability for teaching activity determines the competence of the teacher. In modern psychology and pedagogy, it is regarded as a set of professional and personal qualities.

The basis for the implementation of inclusive education in Ukraine is the foreign experience of Europe and the world, which was studied by Ukrainian scientists N. Ashytok, H. Davydenko, M. Zakharchuk, Yu. Zakaulova, A. Kolupaieva and others. At the training of diverse specialists, taking into account the new philosophy of education, noted leading scientists of special education: Vit. Bondar, A. Kolupaieva, O. Danylavichute, O. Martynchuk, A. Shevtsov and others. The professional training of the future teacher for work in an inclusive environment of a general secondary educational institution is studied by researchers O. Hordiichuk, O. Hnoievska, I. Khafyzullyna, Z. Shevtsiv, M. Shved and others.

Academic communities in different countries are exploring the issue of inclusive education teacher training, namely: N. Pantić, A. Closs \& V. Ivošević, A. Hodkinson, Ofsted Scott, Vitale \& Masten and others.

Qualitative organization of professional training of a competent teacher who is ready and able to work in an inclusive environment of a general educational institution will allow effective implementation of inclusive education. In domestic and foreign pedagogy there is experience in research of problems of professional readiness formation of the teacher. However, this pedagogical problem has never been developed. 
The European Agency for Special and Inclusive Education ${ }^{1}$, is conducting a study of competencies defining the profile of an inclusive education teacher, of which the main competencies are: motivational and value, cognitive, organizational and reflective ${ }^{2}$. Thus, a teacher's activity in an inclusive environment of a general secondary educational institution will provide knowledge, skills and abilities in special pedagogy, beliefs and values, which are formed by means of humane pedagogy, will make it possible to perceive, support and educate all students of a diverse student group. Unfortunately, traditional education at a higher educational institution in Ukraine does not contribute significantly to the formation in a future teacher of inclusive values and a world view of the perception of students with disabilities as subjects of education in general educational institution.

The problems identified encouraged us to investigate a pedagogical system for the professional training of future teachers of specialty 013 "Primary education", which will provide the necessary educational training for a graduating student of a higher educational institution for their multifunctional activity in an inclusive environment of a general secondary educational institution.

The objective of this study is to identify the problems associated with the introduction of inclusive education in Ukraine, to substantiate the pedagogical system of preparing future teachers for inclusive education of students with special educational needs in general secondary educational institutions and to test its impact on the effectiveness of forming their social and pedagogical competence to work in an inclusive environment. In order to achieve this objective, the following questions should be answered:

1. What are the issues that have motivated the study on the training of a future inclusive education specialist?

2. What is the basis for the professional training of future teachers of inclusive education in general secondary educational institution?

3. What is the effectiveness of the proposed pedagogical system for preparing future primary school teachers for work in an inclusive environment of general secondary educational institutions?

1 Офіційний сайт Європейської агенції 3 особливих освітніх потреб та інклюзивної освіти. URL: https://www.european-agency.org/country-information/italy/ legislation-and-policy (дата звернення: 23.02.2019).

${ }^{2}$ Teacher Education for Inclusion Profile of Inclusive Teachers. European Agency for Development in Special Needs Education. URL: https://www.european-agency.org/sites/ default/files/Profile-of-Inclusive-Teachers.pdf (дата звернення: 20.02.2019). 


\section{Problems of professional teacher preparation for inclusive education in general secondary educational institutions of Ukraine}

The practice of introducing inclusive education into the general education system in Ukraine is complex and controversial. Firstly, it is associated with the presence of undisputed myths, namely:

1) children with special educational needs in the classroom are exiles. They will be bullied by classmates; teachers do not know how to teach children with special educational needs and are afraid to do something wrong;

2) in the classroom, all the attention of teachers will be focused on students with special educational needs;

3) all other children will "lose" because of it;

4) when students with special educational needs are in a class with everyone, the overall level of knowledge is reduced due to different curricula;

5) the assistant teacher works in an inclusive class only with a child with special educational needs;

6) a child with special educational needs is a child who is falling behind ${ }^{3}$.

It is therefore worth noting that the introduction of inclusive education is a long-term project that requires primary school teachers to be prepared to work in an inclusive environment.

Secondly, starting from the $90^{\mathrm{s}}$ of the XX century the European Union countries have switched to the program of social inclusion of people with disabilities. The Salamanca Statement, which defined the principles of inclusive education, served as the reference document for the provision of special educational needs, such as: access to residential education for all children, regardless of their physical, intellectual, social, emotional, language or other specific characteristics. The disregard of the "Education for All" program and the educational principles set out in the Salamanca Statement and the implementation of inclusive education in Ukraine is linked to the disregard of some marginalized groups of students whose problems are not related to health but who also need assistance in obtaining education. It is worth mentioning that it emphasizes the need for special training in the field of inclusive education for persons with special educational needs, which allows for obtaining additional specialization,

${ }^{3}$ Семко О. Нова украӥнська школа. URL: https://nus.org.ua/articles/6-mifiv-proinklyuziyu-chogo-ne-varto-boyatysya-ta-obgovoryuvaty-vserjoz/ (дата звернення: 23.12.2019). 
which is combined with the specialization of general secondary education teacher ${ }^{4}$.

In the fourth place, Ukraine is developing a neo-social model of inclusive education, which is seen as a dialectical synthesis of medical and social models that consider an active approach for disability overcoming ${ }^{5}$. In our opinion, a non-social model is a variation of the rehabilitation model that ensures integration of a person with a disability into society, and therefore considers disability as a defect that should be corrected by a team of specialists on medical, physical and psychological rehabilitation in an inclusive resource center. Therefore, the implementation of such a model does not solve the educational needs of persons with disabilities, and certainly not create the conditions for the training of future primary school teachers to work with students with disabilities in the general secondary educational institution. In Ukraine, the attention is focused on training of specialists who obtain qualification in the field of special education.

But, according to Vit. Bondar, important conditions for the effectiveness of inclusive education are the preparation of general education teachers for general and special tasks at a level no lower than that of the current special education system, the definition of the functions of an inclusive class teacher, other specialists, parents of such children and their interaction ${ }^{6}$.

In the fifth place, the UNESCO Round Table on Planning for Inclusive Education stresses the necessity of training teachers in the field of inclusive education. It is stated that there is a missing link between initial training of future teachers in higher educational institutions and professional development of teachers. It is confirmed that the starting point for the training of future inclusive education specialists is the professional development in higher educational institutions ${ }^{7}$.

In the sixth place, the controversial interpretation of the term "inclusive education" and understanding of its essence make it difficult for teachers in Ukraine to obtain professional training to work in an inclusive environment in general secondary educational institutions. Inclusive education as a social

${ }^{4}$ Саламанская декларация. Рамки действий по образованию лиц с особыми потребностями : материалы Всемирной конференции по образованию лиц с особыми потребностями, Саламанка. Испания, 7-10 июня 1994 г. ЮНЕСКО, 1994. $40 \mathrm{c}$.

5 Шевцов А. Освітні освіни системи реабілітування осіб 3 обмеженнями життєдіяльності : автореф. дис. ... докт. пед. наук: 13.00.03. Київ, 2010. 45 с.

${ }^{6}$ Бондар В. Інклюзивне навчання як соціально-педагогічний феномен. Рідна школа. 2011. № 3. С. 10-14.

${ }^{7}$ UNESCO. Inclusion in education Education transforms lives Leading Education 2030. URL: https://en.unesco.org/themes/inclusion-in-education (дата звернення: 20.02.2019). 
phenomenon will be seen from the perspective of interpreting the "inclusion" and "education" terms. Therefore, from the standpoint of traditional pedagogy, the term "education" is a social phenomenon, the main purpose of which is to ensure the assimilation of systematized knowledge and the formation of a worldview on the basis of it, the development of cognitive opportunities, as well as the acquisition by students of competencies for the practical application of general educational knowledge. Obtaining a certain education ensures a certain status in society. The main way to obtain education is through learning. The term "inclusion" (involvement) is a process that allows to involve all children in the process of learning through general secondary educational institutions, and therefore to achieve a certain level of knowledge. However, the introduction of inclusive education for children with special educational needs in Ukraine is being carried out through the establishment of inclusive resource centers that provide qualified support for children with special educational needs aged from 2 to 18 years.

According to legislative documents on inclusive education, the collaborative learning of diverse students in a group requires interaction of teacher and teacher assistant. The problem was studied by scientific communities of different countries. In particular, the understanding of roles and responsibilities in educational process management in the general secondary educational institution, the definition of responsibilities between teacher and assistant; it has been found that teachers are seen by most as the main players in the implementation of inclusive education ${ }^{8}$.

The research of L. Florian, H. Linklater shows that teachers do not have the necessary knowledge and skills to teach all students in an inclusive school class together, and are unable to communicate with a team of specialists who assist in the adaptation processes of students with special educational needs. They found that student learning effectiveness in inclusive classes should be seen as a teacher problem, rather than a student problem ${ }^{9}$.

In the context of the introduction of inclusion in the Ukrainian educational system, the requirements for the professional competence of future specialists and their preparation for pedagogical activity as a whole are increasing, which in turn leads to the need to develop the special

${ }^{8}$ Boer Anke de, Pijl Sip Jan, Minnaert Alexander. Regular primary schoolteachers' attitudes towards inclusive education : A review of the literature. Journal of Inclusive Education. 2010. № 15. P. 331-353. DOI: 10.1080/13603110903030089.

${ }^{9}$ Florian L., Linklater H. Teacher training for inclusive education: the use of inclusive pedagogy to increase the efficiency of teaching and learning for all. Cambridge Journal of Education. 2010. Iss. 4. 369 p. 
competence of an inclusive education specialist for both teachers and teacher assistants in inclusive education.

Studies of L. Florian, K. Young, M. Rouse indicate that traditional strategies of future teachers education, which are used in higher education institutions, can be adapted to the professional training of future inclusive education specialists ${ }^{10}$. Scientists such as L. Florian, K. Black-Hawkins, noted that the discipline of "Inclusive Pedagogy" as a science is important for the training of future specialists in inclusive education and is a leading course that defines important theoretical and didactic foundations of inclusive education pedagogy ${ }^{11}$.

An analysis of a study of educational content on inclusive education indicates what will ensure the initial theoretical, didactic and organizational preparation of future teachers for inclusive education; inclusive pedagogy as a science on the art of upbringing and education of students holds a worthy place. The object, subject and content of inclusive education are defined in the subject "Fundamentals of Inclusive Pedagogy". The subject, subject and content of inclusive education are defined in the educational subject "Fundamentals of Inclusive Pedagogy", which will generate new worldviews of the education of students needing educational support in the learning process, will contribute to the competence formation and the competencies in the activities of future teachers, regardless of their specialization, age, subject and type of educational institution.

Thus, the urgent task of the present in Ukraine is to solve a number of problems, such as:

1. Preparation of a number of qualified specialists for inclusive resource centers: rehabilitation specialists, correctional teachers, speech therapists, social pedagogues / social workers, etc.

2. The introduction of inclusive education and the organization of inclusive learning in general secondary educational institutions determined the emergence of new scientific knowledge from the methodology of inclusive education - a modern branch of pedagogical science - inclusive pedagogy, which is a source of competence of primary school teachers in inclusive education.

${ }^{10}$ Florian L., Young K., Rouse M. Preparing teachers for inclusive and diverse educational environments: Studying curricular reform in an initial teacher education course. International Journal of Inclusive Education. 2010. № 14 (7). P. 709-722.

${ }^{11}$ Florian L., Black-Hawkins K. Exploring inclusive pedagogy. British Educational Research Journal. First published on: 20 July 2010 (iFirst). DOI: 10.1080/01411926.2010.501096.

12 Шевців 3. Основи інклюзивної педагогіки: підручник. 2-ге вид., випр., доп. Львів : Новий світ - 2000, 2019. 264 с. 
3. Attention is focused on the corrective and developmental direction of inclusive education in inclusive rehabilitation centers, the aim of which is to accompany a child with a disability to meet his/her needs as a person with disability.

4. The pedagogical aspect of the inclusive education model is ignored and is not seen as a whole system of inclusive education, the final result of which is a qualitative education, but as the fulfillment of the learning needs of a child with disabilities. Qualitative teaching and education as the final result should only be provided by a primary school teacher with a relevant specialization, since he is a state-approved specialist responsible for the effective teaching of students with special educational needs.

5. The absence in the profession classifier of an inclusive education specialist, an inclusive primary school teacher who is able to professionally operate in an inclusive environment of a general secondary educational institution and collaborate with a team of specialists, that makes the training of future primary school teachers to work in an inclusive environment relevant, resulting in a lack of appropriate competencies of future specialists for inclusive learning in general secondary educational institutions.

Therefore, in accordance with domestic legislation, general education teachers provide education for children with special educational needs in inclusive schools. And that is where the main danger to the success of inclusion lies so far. The inability of teachers to properly plan work with children with developmental disorders, to adapt and modify curricula, and to use correction-oriented teaching methods significantly complicates the effectiveness of teaching and educating of a special child. A significant problem is the appointment of teachers and assistant teachers without special education to the inclusive classes. The above identified problems therefore allow us to define the essence of a teacher training system for future inclusive education teachers.

\section{Pedagogical system for the professional training of future teachers to work in an inclusive environment of general secondary educational institutions}

The pedagogical system of professional training of future primary school teachers for inclusive education in general secondary educational institutions is interpreted as a complex process of students and teachers activities, which results in the acquisition of knowledge and the formation of practical skills, the necessary ways of future activities, ensuring the ability to carry out 
different types of professional activities and improving their personal qualities for that work ${ }^{13}$.

The pedagogical system is seen as a set of elements that are naturally connected with each other and is a certain holistic formation. The aim of the pedagogical system development is to prepare a graduate for future work in an inclusive environment of a general secondary educational institution. It reproduces the essence of the work in an inclusive environment. The pedagogical system allows students to be «immersed» in a specially simulated learning process in which a graduate of a higher educational institution forms an integrated social and pedagogical competence of an inclusive education specialist ${ }^{14}$. That includes:

- development of necessary and sufficient adequacy and competencies in inclusive education;

- training in "The basics of inclusive pedagogy" course;

- approbation of lecture, practical and laboratory lessons, individual and independent student work and practical training;

- implementation of the above theses with the help of innovative teaching methods and means.

Approbation of the developed author's pedagogical system was focused on:

1) modification of the existing curricula of the cycle of professional and practical training of primary school teachers ("Introduction to the specialty", "Basics of pedagogy" (I course), "Didactics" (II course); "Basics of Pedagogical Research", "Organization and Management in Primary Education" (III course); "Pedagogical Practice" (III-IV course);

2) development of the author's program "Basics of Inclusive Pedagogy" (II course) and a special course "Basics of Social and Pedagogical Activity" (I master's course);

3) preparation of integrated teaching-methodical complexes for academic disciplines;

4) development of author's textbook "Fundamentals of Inclusive Pedagogy";

5) preparation of the topics and content of seminars for teachers of general secondary educational institution and teachers of pedagogical disciplines of higher educational institution.

${ }^{13}$ Шевців 3. Педагогічна система професійної підготовки майбутніх учителів початкової школи до роботи в інклюзивному середовищі. Нова педагогічна думка : науково-методичний журнал. Рівне : Рівненський обласний інститут післядипломної педагогічної освіти, 2017. № 2 (90). С. 57-61.

14 Шевців 3. Теорія і методика професійної підготовки майбутніх учителів початкової школи до роботи в інклюзивному середовищі загальноосвітнього навчального закладу : автореф. дис. ... докт. пед. наук: 13.00.04. Рівне, 2017. 45 с. 
The result of the professional training of future primary school teachers for inclusive education in general secondary educational institutions is sociopedagogical (hereinafter inclusive) competence, interpreted as an indicator of integrated personal new formation, characterized by a synthesis of theoretical socio-inclusive knowledge, practical skills and abilities, personally significant and professionally important qualities necessary for the readiness to carry out successfully socio-pedagogical activities and the ability to use them to solve standard and non-standard socio-pedagogical situations and problems associated with the education of diverse students in an inclusive class of general secondary educational institution [26]. Inclusive competence consists of the unity of cognitive and activity components, personal specialized and professionally important qualities of a primary school teacher.

Sample of Research. The pedagogical experiment involved a representative sample of 411 students of Rivne State University for the Humanities, specializing in "Primary Education", divided into two groups: an experimental group (EG) with 215 students, a control group (CG) with 196 second-year students and 72 fifth-year students (masters). In the experimental group the educational and methodical support of the pedagogical system was modernized as well as were introduced innovative teaching technologies. Students in the control group were educated in the traditional form.

The pedagogical experiment required comparison of the results of the formation level of structural components of the socio-pedagogical competence model of the control and experimental groups to establish the changes that occurred in the experimental group in comparison with the control group.

Instrument and Procedures. In the process of conducting the scientific study, a diagnostic map was used, which included: Theoretical (search and bibliographic, system, object and subject analysis, content analysis, abstraction and modeling), empirical (monitoring, psychological and pedagogical diagnostics, pedagogical experiment, qualitative and quantitative analysis of results) methods and techniques of mathematical statistics. The pedagogical system for the professional training of future primary school teachers to work in an inclusive environment of general secondary educational institutions has proved its effectiveness through a pedagogical experiment.

The cognitive component of inclusive competence was diagnosed using psychological and pedagogical methods (the analysis of students academic progress), the method of "unfinished proposal", the method of analysis of learning documentation, narrative methods. The activity component was formed using the expert assessment method based on the results of 
pedagogical practices, the included observation method, the method of analysis of social and pedagogical situations, and author's questionnaire. The motivational component was diagnosed using the method "Motivation of studying at a higher educational institution" (T. Ilina). For diagnostics of professional orientation, responsibility, independence, mobility, ability to plan personal activities, we applied the method "Diagnostics of personality for motivation to success", method of expert evaluation on the results of research work, results of participation in academic competitions, scientific and practical conferences; emotionality - methodology for determining empathic abilities of V. Boiko, the methodology of "The scale of benevolence" (according to the Campbell scale), values - methodology of "Value Orientations" (M. Rokych).

According to the results of the experiment we came to the conclusion about the positive influence of the implemented pedagogical system. The summary results of the comparative analysis obtained during their diagnosis are presented in table 1 .

Table 1

Dynamics of the levels of structural components of socio-pedagogical competence formation of future primary school teachers to work in an inclusive environment of general educational institutions

\begin{tabular}{|c|c|c|c|c|c|c|c|c|}
\hline \multicolumn{2}{|c|}{ Components } & \multirow{2}{*}{$\begin{array}{l}\text { Levels of } \\
\text { formation }\end{array}$} & \multicolumn{2}{|c|}{$\begin{array}{l}\text { Before the } \\
\text { beginning }\end{array}$} & \multicolumn{2}{|c|}{$\begin{array}{l}\text { After the } \\
\text { ending }\end{array}$} & \multicolumn{2}{|c|}{$\begin{array}{c}\text { Dynamics } \\
\Delta\end{array}$} \\
\hline & & & $\mathrm{CG}$ & EG & CG & EG & $\mathrm{CG}$ & EG \\
\hline \multirow{3}{*}{\multicolumn{2}{|c|}{ Cognitive }} & Sufficient & 50,0 & 59,1 & 49,5 & 33,5 & $-0,5$ & $-25,6$ \\
\hline & & Average & 39,8 & 31,6 & 39,8 & 41,8 & 0 & $+10,2$ \\
\hline & & High & 10,2 & 9,3 & 10,7 & 24,7 & $+0,5$ & $+15,4$ \\
\hline \multirow{3}{*}{\multicolumn{2}{|c|}{ Activity }} & Sufficient & 58,7 & 56,8 & 49,5 & 33,5 & $-9,2$ & $-23,3$ \\
\hline & & Average & 32,1 & 33,0 & 39,8 & 41,8 & $+7,7$ & $+8,8$ \\
\hline & & High & 9,2 & 10,2 & 10,7 & 24,7 & $+1,5$ & $+14,5$ \\
\hline \multirow{9}{*}{ 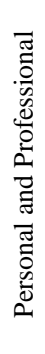 } & \multirow{3}{*}{$\begin{array}{c}\text { Motivation- } \\
\text { directed }\end{array}$} & Sufficient & 5,6 & 4,2 & 4,5 & 1,9 & $-1,1$ & $-2,3$ \\
\hline & & Average & 18,9 & 21,9 & 18,4 & 16,3 & $-0,5$ & $-5,6$ \\
\hline & & High & 75,5 & 73,9 & 77,1 & 81,8 & $+1,6$ & $+7,9$ \\
\hline & \multirow{3}{*}{ Emocional } & Sufficient & 36,2 & 42,3 & 35,2 & 33,4 & -1 & $-8,9$ \\
\hline & & Average & 45,9 & 32,6 & 46,4 & 38,2 & $+0,5$ & $+5,6$ \\
\hline & & High & 17,9 & 25,1 & 18,4 & 28,4 & $+0,9$ & $+3,3$ \\
\hline & \multirow{3}{*}{ Axiological } & Sufficient & 38,8 & 45,1 & 38,2 & 36,3 & $-0,6$ & $-8,8$ \\
\hline & & Average & 44,4 & 31,6 & 43,9 & 34,0 & $-0,5$ & $+2,4$ \\
\hline & & High & 16,8 & 23,3 & 17,9 & 29,8 & $+1,1$ & $+6,5$ \\
\hline
\end{tabular}

The results of the pedagogical experiment revealed that the inclusive competency of future primary school teachers to work in an inclusive 
environment in a general secondary educational institution has increased significantly. In particular, the number of students with a high level of cognitive and activity component - by $15,7 \%$ and $14,4 \%$, respectively, with an average level by $-10,2 \%$ and $8,8 \%$, respectively, decreased competence at a sufficient level with the cognitive component by $25,5 \%$, and for activity - by $23,3 \%$. The number of students with a high level of personal and professional component of inclusive competence by motivational, emotional and axiological components increased by 7,9\%, 3,3\% and 6,5\% respectively, by $5,6 \%$ and $2,4 \%$ on average level, and decreased by $8,9 \%$ on motivational, sufficient level of all components decreased by 2,3\%, $8,9 \%$ and $8,8 \%$ respectively.

\section{Discussion}

Our approach to the professional training of future inclusive education specialists is determined by the problems, realities and perspectives in the implementation of inclusive education in Ukraine.

The problem with the implementation of inclusion in education is that it is considered not as a holistic system of inclusive learning, the final result of which is qualitative education, but as meeting the individual needs of a child with a disability. The realities of teacher preparation for inclusive education are as follows:

- the ignoring of the «Education for All» programme and the principles of education contained in the Salamanca Declaration, obviously some marginalized groups of learners whose problems are not related to health also being ignored, although they need education assistance as well. We believe that the term "children with special educational needs" should be improved. It is appropriate to use the term "children with special educational support";

- the attention is focused on the corrective and rehabilitative direction of the medical model of disability and its pedagogical aspect is ignored. There are established and separately functioning institutions of inclusive education, such as: inclusive groups in preschool education institutions, inclusive classes in general secondary educational institutions and inclusive rehabilitation centers. Their activities at the local level are not aimed at accompanying a disabled student to meet his or her needs in general and in particular the needs for education, correction and rehabilitation. The training process in educational institutions focuses not on the obtaining of education, but on the correction and rehabilitation of health;

- qualitative training and as an end result - education is provided only by a primary school teacher with a relevant specialization. Since the teacher is a 
State-authorized professional who provides services in an educational institution, he is responsible for the effective education of students with special educational needs. However, there is no specialist of the corresponding profession in the current Classifier of Professions in Ukraine, and the right of autonomy granted to institutions provides an opportunity to obtain specialization of teachers of inclusive education in pedagogical institutes as part of training of future primary school teachers;

- due to the lack of pedagogical knowledge about inclusive education, the qualitative training of future primary school teachers is based on a mixed method of social and inclusive knowledge with general pedagogy, didactics and theory of education. The curriculum for the training of students during the introduction of inclusive education included a course on the pedagogy of inclusive education, the methodical support for which was not developed and the definition of the term was interpreted differently. The problem has predetermined us to justify inclusive pedagogy as a science of the field of pedagogy, to define its methodology, role, place, universal definition and content that focuses on preparing of future primary school teachers for inclusive learning, to help students to overcome learning difficulties caused by illness or other factors.

\section{CONCLUSIONS}

The pedagogical experiment was carried out after the clarification of the sectoral standards of higher education in the "Primary education" specialty, taking into account the content of inclusive education, through the introduction of a common methodology for the professional training of future primary school teachers, based on the technologies of problem, contextual and personal-oriented learning, interactive teaching methods, traditional and non-traditional forms of organization of students educational activities. The methodology of professional training for inclusive education has been implemented in all forms of education at higher educational institutions by immersing students in their future professional activities, namely: at laboratory-practical lessons, in the course of pedagogical practice, during independent work and fulfillment of research tasks, during practice of innovative methods and technologies of education.

The level of formation of components of the socio-pedagogical competence of a primary school teacher to inclusive learning was assessed through testing, questionnaires, situation management and etc. The results give us the grounds to state that the experimental pedagogical system for the professional training of future specialists had a positive impact on the growth of readiness and ability of primary school teachers to work in an 
inclusive environment of the general secondary educational institution and showed a positive dynamics of growth in the level of formation of each of its components. In order to test the developed hypothesis, the criterion $\chi^{2}$ ( chi-square) was applied, at $\alpha=0,05$.

This has confirmed the effectiveness of the experimental pedagogical system for training of future primary school teachers in readiness and ability for inclusive education in general secondary educational institutions.

\section{SUMMARY}

The article summarizes the main problems of inclusive education implementation in Ukraine [17]. In the article are identified main problems that hinder the successful professional preparation of future primary school teachers to work in the inclusive environment of a general secondary education institution. It emphasizes the need to develop a pedagogical system of the educational process of the institution of higher education and the necessary and sufficient volume of competences of the teacher of inclusive education. The pedagogical system includes modification of the current curricula of the subjects of the cycle of vocational and practical training of elementary school teachers, development of the author's textbook "Fundamentals of inclusive pedagogy", development of the author's educational program, testing of lectures, practical and laboratory classes, individual and independent work.

The purpose of introduction of the pedagogical system was to identify the level of competence of the future teacher for pedagogical activity in the conditions of inclusion. The analysis of the pedagogical experiment data gives grounds for claiming that the experimental pedagogical system of preparing future primary school teachers of general secondary education to work in an inclusive environment had a positive effect on the growth of their competence. Based on the stated in the experimental group cognitive competence increased by $25,5 \%$, activity by $23,3 \%$, personal - by motivational, emotional and axiological components increased by $7,9 \%$, $3,3 \%$ and $6,5 \%$, respectively [26]. It is proved that the implementation of pedagogical system of preparation of students in higher education institutions of Ukraine for inclusive education provides a level of personal readiness and quality of professional knowledge.

\section{REFERENCES}

1. Ашиток Н. Проблеми інклюзивної освіти в Україні. Людинознавчі студії. ерія «Педагогіка». 2015. Вип. 1/3. С. 4-11. URL: 

звернення: 17.01.2017).

2. Бондар В. Інклюзивне навчання як соціально-педагогічний феномен. Рідна школа. 2011. № 3. С. 10-14.

3. Будник О. Теоретичні і методичні засади професійної підготовки майбутніх учителів початкових класів до соціально-педагогічної діяльності : дис. ... докт. пед. наук: 13.00.04. Житомир, 2015. 552 с.

4. Вчитель i асистент: ролі і відповідальність. URL: http://www.education-inclusive.com/wp-content/docs/ATATeacher_and_Teachers_Assistants_Roles_and_Responsibilities_.UKR.pdf (дата звернення: 11.01.2019).

5. Гордійчук О. Науково-методична робота як складова професійної підготовки майбутніх вчителів початкових класів до інклюзивної діяльності. URL: http://45pdfAdobeAcrobatDocument (дата звернення: 27.01.2017).

6. Гноєвська О. Формування корекційної компетентності вчителя загальноосвітнього закладу з інклюзивною формою навчання : автореф. дис. ... канд. пед. наук: 13.00.03. Київ, 2016. 17 с.

7. Давиденко Г. Теоретико-методичні засади організації інклюзивного навчання у вищих навчальних закладах країн Європейського Союзу : дис. ... докт. пед. наук: 13.00.01. Київ, 2015. 467 с.

8. Данілавічюте Е., Литовченко С. Стратегії викладання в інклюзивному навчальному закладі : навчально-методичний посібник / за ред. А. Колупаєвої. Київ : Видавнича група «А.С.К.», 2012. 360 с.

9. Демченко І. Алгоритм квазіпрофесійної підготовки майбутнього вчителя початкових класів до роботи в умовах інклюзивної освіти. Психолого-педагогічні проблеми сільської школи. 2013. № 45. С. 40-49.

10. Захарчук М., Закаулова Ю. Аналіз системи підготовки педагогів інклюзивної школи у США. Науковий вісник Мелітопольського державного педагогічного університету. Серія «Педагогіка». 2014. № 1. C. 21-28.

11. Лорман Тім, Деппелер Джоан, Харві Девід. Інклюзивна освіта. Підтримка розмаїття у класі : практичний посібник. Пер. 3 анг. Київ : СПД-ФО І.С. Парашин, 2010. 296 с.

12. Колупаєва А.А. Інклюзивна освіта: реалії та перспективи : монографія. Київ : Самміт-книга, 2009. 272 с.

13. Мартинчук О.В. Сутність поняття та зміст професійної компетентності фахівців у сфері інклюзивного навчання дітей 3 тяжкими порушеннями мовлення. Науковий часопис Національного педагогічного унверситету імені М.П. Драгоманова. Серія 19 
«Корекційна педагогіка та спеціальна психологія». 2014. Вип. 28. C. 130-136. URL: http://nbuv.gov.ua/UJRN/Nchnpu_019_2014_28_30 (дата звернення: 17.11.2019).

14. Національний класифікатор України. Класифікатор професій. URL: http://hrliga.com/docs/327_KP.htm (дата звернення: 23.02.2017).

15. Офіційний сайт Європейської агенції 3 особливих освітніх потреб та інклюзивної освіти. URL: https://www.europeanagency.org/country-information/italy/legislation-and-policy (дата звернення: 23.02.2019).

16. Саламанская декларация. Рамки действий по образованию лии с особыми потребностями : материалы Всемирной конференции по образованию лиц с особыми потребностями, Саламанка. Испания, 710 июня 1994 г. ЮНЕСКО, 1994. 40 с.

17. Семко O. Нова українська школа. URL: https://nus.org.ua/articles/ 6-mifiv-pro-inklyuziyu-chogo-ne-varto-boyatysya-ta-obgovoryuvatyvserjoz/ (дата звернення: 23.12.2019).

18. Філоненко М. Психологія особистісного становлення майбутнього лікаря : автореф. дис. ... докт. психол. наук: 19.00.07. Київ, 2016. $43 \mathrm{c}$.

19. Хафизуллина И. Н. Формирование инклюзивной компетентности будущих учителей в процессе профессиональной подготовки : автореф. дис. ... канд. пед. наук: 13.00.08. Астрахань, 2008. 22 с. URL: http://www.dissercat.com/content/formirovanie-inklyuzivnoi-

kompetentnosti-budushchikh-uchitelei-v-protsesse-professionalnoi-p (дата звернення: 06.05.2016).

20. Швед М. Основи інклюзивної освіти : підручник. Львів : Український католицький університет, 2015. 360 с.

21. Шевців 3. Педагогічна система професійної підготовки майбутніх учителів початкової школи до роботи в інклюзивному середовищі. Нова педагогічна думка : науково-методичний журнал. Рівне : Рівненський обласний інститут післядипломної педагогічної освіти, 2017. № 2 (90). С. 57-61.

22. Шевців 3. Діагностика сформованості соціально-педагогічної компетентності у майбутнього вчителя початкових класів. Педагогічні науки : збірник наукових праць / Херсонський державний університет. Херсон : «Видавничий дім «Гельветика»», 2016. Випуск LXXIII. T. 2. C. $127-133$.

23. Шевців 3. Концепція соціально-педагогічної компетентності у майбутнього вчителя початкових класів інклюзивної загальноосвітньої школи. Педагогічні науки : збірник наукових праць / Херсонський 
державний університет. Херсон : «Видавничий дім «Гельветика»», 2016. Вип. LXXIY. T. 3. С. 117-122.

24. Шевців 3. Основи інклюзивної педагогіки : підручник. 2-ге вид., виправл., доп. Львів : Новий світ - 2000, 2019. 264 с.

25. Шевців 3. Сутність і структурні компоненти соціальнопедагогічної компетентності майбутнього вчителя початкових класів інклюзивної загальноосвітньої школи. Теорія $і$ методика професійної освіти : електронне наукове фахове видання. 2016. Вип. № 11 (3). URL: http://tmpo.ivet-ua.science (дата звернення: 20.02.2018).

26. Шевців 3. Теорія і методика професійної підготовки майбутніх учителів початкової школи до роботи в інклюзивному середовищі загальноосвітнього навчального закладу : автореф. дис. ... док. пед. наук: 13.00.04. Рівне, 2017. 45 с.

27. Шевцов А. Освітні освіни системи реабілітування осіб 3 обмеженнями життєдіяльності : автореф. дис. ... док. пед. наук: 13.00.03. Київ, 2010. 45 с.

28. Boer Anke de, Pijl Sip Jan, Minnaert Alexander. Regular primary schoolteachers' attitudes towards inclusive education: A review of the literature. Journal of Inclusive Education. 2010. № 15. P. 331-353. DOI: 10.1080/13603110903030089.

29. Florian L., Linklater H. Teacher training for inclusive education: the use of inclusive pedagogy to increase the efficiency of teaching and learning for all. Cambridge Journal of Education. 2010. Iss. 4. 369 p.

30. Florian L., Black-Hawkins K. Exploring inclusive pedagogy. British Educational Research Journal. First published on: 20 July 2010 (IFirst). DOI: 10.1080/01411926.2010.501096; accessed 21 July 2010.

31. Florian L., Young K., Rouse M. Preparing teachers for inclusive and diverse educational environments: Studying curricular reform in an initial teacher education course. International Journal of Inclusive Education. 2010. № 14 (7). P. 709-722.

32. Hodkinson A. Inclusive and special education in the English educational system : historical perspectives, recent developments and future challenges Research in Education. 2010. № 73. P. 15-29.

33. Oftsted. Special educational needs and disabilities: Towards inclusive schools. London : Ofsted, 2004.

34. Pantić N., Closs A., Ivošević V. Teachers for the future: Teacher development for inclusive education in the Western Balkans. Torino, Italy : European Training Foundation, 2011. 
35. Scott B., Vitale M., Masten W. Implementing instructional adaptations for students with disabilities in inclusive classrooms: A literature review. Remedial and Special Education. 1998. № 19 (2). P. 106-119.

36. Teacher Education for Inclusion Profile of Inclusive Teachers. European Agency for Development in Special Needs Education. URL: https://www.european-agency.org/sites/default/files/Profile-of-InclusiveTeachers.pdf (дата звернення: 20.02.2019).

37. UNESCO. Inclusion in education Education transforms lives Leading Education 2030. URL: https://en.unesco.org/themes/inclusion-in-education (дата звернення: 20.02.2019).

\section{Information about the authors:}

Shevtsiv Z. M., Doctor of Pedagogy, Professor of the Department of Pedagogy of Primary Education Rivne State Humanities University 31, Plastova str., Rivne, 33000, Ukraine ORCID ID: orcid.org/0000-0002-0745-4625

Filonenko M. M., Doctor of Psychology, Professor of the Department of General and Medical Psychology Bogomolets National Medical University 34, Avenue Pobedy, Kyiv, 02000, Ukraine ORCID ID: orcid.org/0000-0001-9976-1165 